Patrycja Zaremba

Akademia Marynarki Wojennej im. Bohaterów Westerplatte w Gdyni, Wydział Dowodzenia i Operacji Morskich

\title{
Nowe wyzwania dla NATO. Sojusz Północnoatlantycki w obliczu zagrożeń hybrydowych
}

DOI: $10.19195 / 1643-0328.24 .10$

Słowa kluczowe: zagrożenia hybrydowe, wojna hybrydowa, asymetria, hybrydowość, NATO, MOOTW (operacje militarne inne niż wojna)

\section{Wprowadzenie}

Zakończenie zimnej wojny, a co za tym idzie - upadek bipolarnego podziału świata, skutkowały pojawieniem się wielu nowych, dotąd nieznanych, zagrożeń w sferze szeroko ujmowanego bezpieczeństwa i obronności. Przedstawiciele Paktu Północnoatlantyckiego stanęli przed ogromnym wyzwaniem, którego celem było podjęcie zdecydowanych kroków zmierzających do reagowania, a w konsekwencji niwelowania nowo powstających zagrożeń. Niniejszy artykuł stanowi zarys problemu dotyczącego nowej rzeczywistości, w jakiej znalazło się NATO, i próbę odpowiedzi na pytanie, czy jeden z głównych filarów bezpieczeństwa globalnego dysponuje mechanizmami przeciwdziałania i zapobiegania niepożądanym zjawiskom o wielowymiarowym charakterze, jakie niewątpliwie stanowią zagrożenia hybrydowe.

Obecne przeobrażenia w środowisku bezpieczeństwa globalnego pozwalają domniemać, iż charakter pojawiających się zagrożeń oscylować będzie nie tylko w sferze militarnej, lecz skupiać się będzie w głównej mierze na oddziaływaniu w sferze niekonwencjonalnej. Dotychczasowe podejście zarówno organów państwowych, jak i organizacji międzynarodowych odpowiedzialnych za zapewnienie globalnego ładu odnosiło się ściśle do definiowania zagrożeń bezpieczeństwa w ujęciu przedmiotowym. Skupiano się na zjawiskach w sferze militarnej, politycznej, ekonomicznej, ekologicznej czy kulturowej. Jak się później okazało, wspomniana interpretacja stała się dalece niewystarczająca. Narastająca skala zagrożeń o podłożu nieregularnym, tj. terroryzm, wojna podprogowa czy kryzys migracyjny, zmusiła do redefinicji samego pojęcia, jego charakteru oraz skali. 
Głównym celem niniejszego opracowania jest przybliżenie kwestii zagrożeń o charakterze hybrydowym oraz zdolności kontrodpowiedzi NATO na tego typu negatywne zjawiska. Autorka stara się także usystematyzować kwestię terminologii, omawiając szczegółowo pojęcie asymetrii (asymetryczności) i hybrydowości.

\section{NATO jako podmiot bezpieczeństwa globalnego}

Powstała w 1949 r. organizacja o charakterze polityczno-wojskowym uchodzi za jeden z podstawowych filarów bezpieczeństwa międzynarodowego. $Z$ zadań statutowych wynika, iż głównym celem funkcjonowania Sojuszu jest „ochrona wolności, wspólnego dziedzictwa i cywilizacji swych narodów opartych na zasadach demokracji, wolności jednostki i rządów prawa"1. Wspomniane cele osiągane są przede wszystkim przez realizację zapisów art. 1 i 2 Traktatu Północnoatlantyckiego, które zakładają rozwiązywanie wszelkich sporów o charakterze międzynarodowym za pomocą środków pokojowych w taki sposób, aby pokój międzynarodowy oraz bezpieczeństwo i sprawiedliwość nie zostały narażone na niebezpieczeństwo, a także podejmowanie działań przyczyniających się do dalszego rozwoju pokojowych i przyjaznych stosunków międzynarodowych ${ }^{2}$. Wspomniane środki dotyczą przede wszystkim tych o charakterze:

- politycznym: promowanie wartości demokratycznych, zachęcanie do konsultacji i współpracy w zakresie bezpieczeństwa i obronności w celu budowy zaufania i zapobiegania konfliktom;

— militarnym: dążenie do pokojowego rozwiązywania sporów.

Wykorzystanie wachlarza środków dyplomatycznych skutkuje możliwością podjęcia działań wynikających z artykułu 5 Traktatu Waszyngtońskiego. Stanowi on, że:

zbrojna napaść na jedną lub kilka stron w Europie lub Ameryce Północnej będzie uważana za napaść przeciwko nim wszystkim; wskutek tego zgadzają się one na to, że jeżeli taka zbrojna napaść nastąpi, każda z nich [...] udzieli pomocy Stronie lub Stronom napadniętym, podejmując natychmiast indywidualnie lub w porozumieniu z innymi Stronami taką akcję, jaką uzna za konieczną, nie wyłączając użycia siły zbrojnej $[\ldots]^{3}$.

Dwubiegunowość środków będących w posiadaniu Sojuszu pozwala na rozstrzyganie sporów czy też sytuacji kryzysowych w drodze pokojowych rozwiązań osiąganych w wyniku konsultacji i konsensusu pomiędzy stronami. Nierzadko jednak dochodzi do sytuacji, gdy działania polityczne zawodzą, co w konsekwencji przekłada się na wykorzystywanie mechanizmów o podłożu militarnym.

Upadek Związku Radzieckiego w sposób radykalny zmienił percepcję środowiska międzynarodowego, w jakim funkcjonowało NATO. Wydarzenie to skutkowało redefinicją roli Sojuszu w kształtowaniu regionalnego bezpieczeństwa. Na skutek działań podejmo-

${ }^{1} \mathrm{http} / /$ www.stosunki.pl/sites/default/files/images/Traktat\%20P\%C3\%B3\%C5\%82nocnoatlantycki. pdf (dostęp: 10 września 2016).

2 Traktat Północnoatlantycki sporządzony w Waszyngtonie dnia 4 kwietnia 1949 r., Dz.U. z 2000 r. Nr 87, poz. 970.

${ }^{3}$ http://www.nato.int/nato-welcome/index.html (dostęp: 15 października 2016). 
wanych przez OBWE i ONZ Pakt podjął analogiczne kroki zmierzające ku rozszerzeniu statutowych zadań. Konsekwencją wykroczenia poza konstytucyjne ramy obowiązków była zmiana dotychczasowego charakteru NATO. Jak podkreśla J. Dobrowolska-Polak, „sojusz był już nie tylko organizacją zbiorowej samoobrony, ale przede wszystkim przyjął rolę organizacji bezpieczeństwa zbiorowego"4. W 1992 r. NATO włączyło się do wsparcia operacji pokojowych (Peacekeeping) realizowanych dotychczas przez ONZ i OBWE.

Konsekwencją takiego podejścia była konieczność zdefiniowania i wyróżnienia tzw. MOOTW, czyli operacji militarnych innych niż wojna (ang. military operations other than war). W literaturze przedmiotu istnieje wiele synonimów, powszechnie używanych nazw zastępczych omawianego terminu, do których zaliczyć można:

- działania pozawojenne,

- działania poniżej progu wojny,

- działania nieobjęte artykułem 5 Traktatu Waszyngtońskiego,

— działania nieobjęte artykułem 5 Traktatu Północnoatlantyckiego ${ }^{5}$.

Należy także podkreślić, iż mnogość nazewnictwa samego zjawiska w sposób bezpośredni przekłada się na różnorodność powstałych definicji MOOTW. W dokumencie Joint Doctrine for Military Operation Other Than War określono, że operacje inne niż wojna stanowią „wojskowe działania inne niż wojna obejmujące użycie możliwości sił zbrojnych w szerokim zakresie operacji prowadzonych na mniejszą skalę niż wojna"6. Powołując się jednak na definicję ujętą w AJP-01(A)24, można stwierdzić, iż do operacji militarnych innych niż wojna należą działania o szerokim zakresie, podczas których możliwości militarne wykorzystywane są do celów innych niż działania bojowe ${ }^{7}$.

W ramach MOOTW wyróżniono wiele działań wchodzących w zakres Operacji Wspierania Pokoju. Należą do nich:

$-\mathrm{z}$ a p o b i e g a n i e k o n f l i k t o m - opierające się na działaniach dyplomatycznych, zapobiegawczego rozlokowania wojsk, zapobieganie rozprzestrzenianiu się konfliktu oraz jego przeobrażeniom;

- $\mathrm{t}$ w o r z e n i e p o k o j u - działania dyplomatyczne podejmowane w chwili wystąpienia konfliktu, zmierzające do osiągnięcia porozumienia stron walczących;

- u t r z y m y w a n i e p o k o j u - działania opierające się na chęci złagodzenia lub ograniczenia konfliktu między stronami poprzez interwencję międzynarodową wykorzystującą środki zarówno cywilne, jak i wojskowe;

- w y m u s z a n i e p o k o j u - działania oparte o wykorzystanie środków wojskowych, których celem jest przywrócenie pokoju w strefie objętej konfliktem;

4 J. Dobrowolska-Polak, Międzynarodowa solidarność. Operacje pokojowe ONZ, NATO i UE, „IZ Policy Papers" 2009, nr 3, s. 53-57.

${ }^{5}$ http://www.amw.gdynia.pl/library/File/ZeszytyNaukowe/2006/Szubrycht_T.pdf (dostęp: 10 listopada 2016).

6 Joint Publication 3-07, „Joint Doctrine for Military Operation Other Than War”, June 1995, s. I-1.

7 T. Bąk, Udział i sojusznicze współdziałanie żołnierzy WP w operacji pokojowej NATO w Kosowie, Warszawa 2002, s. 12. 
- b u d o w a n i e po k o j u - działania podejmowane bezpośrednio po zakończeniu konfliktu, obejmujące działania utrwalające w sferze politycznej, które zapobiegają ponownej eskalacji konfliktu;

- o p e r a j e h u m a n i t a r n e - misje humanitarne mające na celu niesienie pomocy ludności $\mathrm{w}$ regionach niezdolnych do zaspokojenia podstawowych potrzeb $^{8}$.

Analiza wymienionych operacji $\mathrm{w}$ ramach działań pozawojennych, czy też jak wcześniej wspomniano - działań poniżej progu wojny, nie precyzuje jednak kwestii odpowiedzi na zagrożenia o podłożu hybrydowym. Zagrożenia o charakterze asymetrycznym, potocznie nazywane hybrydowymi, stanowią działania podejmowane na pograniczu środków cywilnych i wojskowych, których głównym celem jest destabilizacja podstawowych struktur funkcjonowania danego podmiotu. W dalszych rozważaniach istotne jest szczegółowe skupienie się na pojęciu asymetrii i hybrydowości.

\section{Pojęcie asymetrii i hybrydowości}

Pojęcie „asymetria” wywodzi się z greki i oznacza brak równowagi w danym układzie przestrzennym lub istniejących relacjach, dominację wartości, zachowań, środków czy też danych ${ }^{9}$.

Przekładając ten termin na potrzeby niniejszego opracowania, można przyjąć, iż asymetria odnosi się nie tylko do dysproporcji w rozkładzie siły militarnej, jak uważa wielu ze współczesnych analityków, lecz także do nierównowagi w sferze materialnej i duchowej pomiędzy poszczególnymi regionami, co w konsekwencji prowadzi do eskalacji konfliktów o różnorakim charakterze. Na takim ujęciu skupia się K. Rokiciński ${ }^{10}$ :

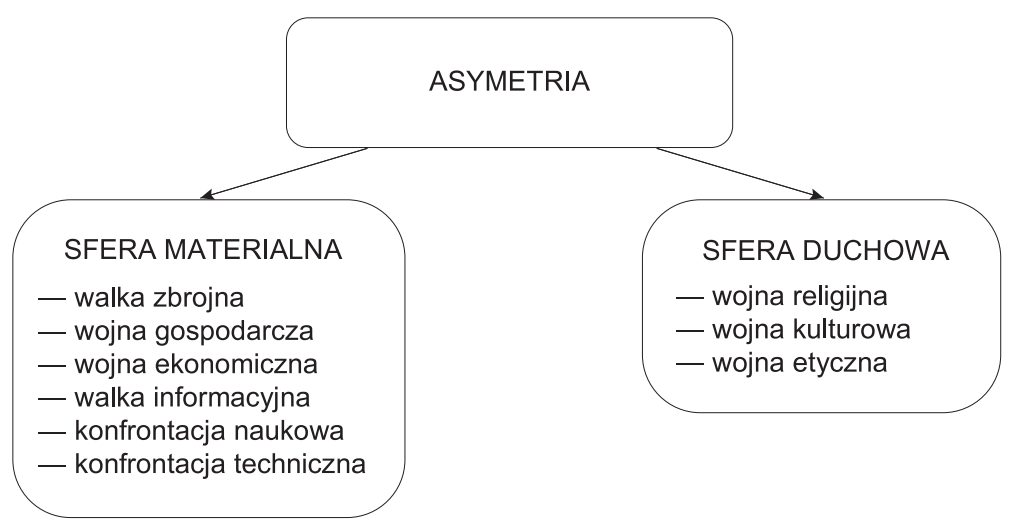

Rycina 1. Asymetria

Źródło: K. Rokiciński, Zagrożenia asymetryczne w Regionie Bałtyckim, Warszawa 2006, s. 14.

${ }^{8}$ M. Marszałek, Operacje wsparcia pokoju według pogląów NATO, Warszawa 1999, s. 14.

${ }^{9}$ http://sjp.pl/asymetria (dostęp: 10 listopada 2016).

10 K. Rokiciński, Zagrożenia asymetryczne w Regionie Bałtyckim, Warszawa 2006, s. 13. 
Jak podkreśla autor, na zjawisko asymetrii składa się dysproporcja występująca w dwóch układach — strefie materialnej i strefie duchowej. Na sferę materialną składają się między innymi walka zbrojna, wojna ekonomiczna, walka informacyjna, jak również konfrontacja naukowa oraz techniczna. Z kolei druga ze sfer dotyczy kwestii wojny religijnej, kulturowej oraz etycznej.

Można zatem pokusić się o stwierdzenie, iż dysproporcja pojawia się wszędzie tam, gdzie występują dwa lub kilka podmiotów zdolnych do podejmowania jednostkowych czy też zunifikowanych działań. Tak więc o dysproporcji, asymetrii mówimy w odniesieniu do rozwoju poszczególnych jednostek, organizacji, a w konsekwencji także do państw, unii, koalicji. Trudno w tym względzie o zachowanie jednolitego stopnia ogólnego wzrostu siły, potencjału, możliwości. Każdy z wymienionych podmiotów prezentuje charakterystyczne dla siebie cechy, pewną specyfikę niemożliwą bądź też trudną do osiągnięcia dla pozostałych aktorów.

Z kolei T. Szubrycht rozprawia o pojęciu asymetryczności w odniesieniu do działań militarnych. Jak podkreśla, omawiany termin nie może być ujmowany jednoznacznie, a za podstawę analizy przyjęte powinno być wcześniejsze określenie kontekstu, płaszczyzny czy też odniesienia. Czynniki te stanowią punkt wyjściowy w dalszych rozważaniach. Autor zaznacza, że jednym z najistotniejszych elementów, wobec których można dokonać klasyfikacji zagrożeń asymetrycznych, jest charakter stron konfliktu. O konflikcie asymetrycznym mówimy w wypadku, gdy strony zaangażowane mają odmienny status w zakresie prawa międzynarodowego, a więc jedna ze stron nie jest uznawana za podmiot owego prawa ${ }^{11}$.

Kolejnym z czynników klasyfikujących konflikt jako asymetryczny jest różnorodność celów działania przez oponentów. Może to przybierać formy celów strategicznych, jak również tych o charakterze taktycznym bądź operacyjnym. Jak podkreśla autor, kluczowym elementem jest czynnik czasu. Argument ten podparto słynną łacińską sentencją: „kropla drąży skałę nie siłą, lecz częstotliwością spadania”. Stanowi to potwierdzenie wcześniejszej tezy zakładającej, iż to nie tylko potencjał militarny przesądza o wyniku konfliktu. Czynnikiem warunkującym jest dodatkowo zjawisko permanentnego działania bądź groźby zastosowania ataku ${ }^{12}$.

Analiza współcześnie występujących zagrożeń pozwala na stwierdzenie, iż wszelkie pojawiające się obecnie zagrożenia generowane są przez brak występowania równowagi, a więc asymetrię wyróżnianą w jednej bądź kilku wymienionych sferach. Coraz częstsze przypadki terroru, działalność grup separatystycznych, bojówek, grup przestępczych czy zjawisko piractwa wynikają jedynie z chęci osiągnięcia równowagi, która jednak w każdym ze wspomnianych wypadków rozumiana jest w odmiennie. Nie sposób przewidzieć skali wynikających z tego zagrożeń. Możliwa jest jedynie ocena kierunków działań oraz charakteru pojawiających się niepożądanych zjawisk.

11 T. Szubrycht, Analiza podobieństw operacji militarnych innych niż wojna oraz działań pozwalających zminimalizować zagrożenia asymetryczne, „Zeszyty Naukowe Akademii Marynarki Wojennej” nr 1, 2006, s. 141.

12 Ibidem, s. 143. 
Niezbędne w tym miejscu jest rozszerzenie dalszych rozważań o termin hybrydowości. Etymologia łacińskiego słowa „hybryda” odsyła do postaci swoistego „mieszańca” powstałego z genetycznego połączenia kilku odmian ${ }^{13}$. Przeobrażenia w sferze szeroko ujmowanego bezpieczeństwa globalnego sprawiły, iż pojęcie to w sposób szczególny zakorzeniło się w rozważaniach analityków wojskowych i publicystów. Okazało się, iż termin hybrydowości w sposób szczególny oddaje istotę nowych zagrożeń, które przybierają różnorakie formy. Hybrydowość stała się swoistym miernikiem ukazującym wielowymiarowość badanego zjawiska. Wszelkie nieznane i trudno klasyfikowane wyzwania i zagrożenia określano mianem zagrożeń hybrydowych. Skutkowało to między innymi faktem coraz częstszego nadużywania wspomnianego pojęcia.

Celem usystematyzowania kwestii definicyjnych warto przytoczyć kilka stanowisk traktujących o szeroko rozumianym pojęciu zagrożeń hybrydowych. Jak podkreśla A. Piotrowski, istotą zagrożeń hybrydowych jest „łączenie przez dany podmiot różnych, pozornie nieprzystających metod i środków prowadzenia walki”" ${ }^{\prime 4}$. Szersze ujęcie proponuje amerykański analityk F.G. Hoffman, który uznaje, iż hybrydowość współczesnych zagrożeń stanowi „zbieżność fizyczną, psychologiczną, kinetyczna i niekinetyczną, bojowników i cywilów, sił zbrojnych i społeczności, państw i aktorów niepaństwowych, a także zdolności bojowych, w które są wyposażone"15. Jak twierdzi ów autor, współczesne państwa stoją w obliczu nieregularnych, często nieznanych zagrożeń, które łączą w sobie cechy klasyczne (tj. walka zbrojna, agresja państwowa) oraz niekonwencjonalne, które przedstawiono na rycinie 1.

Odmienne ujęcie przedstawia J. Nameth, który w definicji wojny hybrydowej wyróżnia, oprócz działań militarnych, sposób oddziaływania na społeczeństwo. Jak podkreśla, na charakterystyczne cechy wojny hybrydowej składają się:

- organizacja armii odzwierciedlająca poziom rozwoju społeczno-ekonomicznego wspólnoty;

— odmienny od zachodniego sposób percepcji militarnej;

- wykorzystywanie nowoczesnych technologii w działaniach taktycznych oraz strategicznych ${ }^{16}$.

Przytoczone rozważania J. Nametha odnosiły się ściśle do konfliktu rosyjsko-czeczeńskiego, jednakże wraz z upływem czasu i narastającą skalą pojawiających się zagrożeń nieregularnych rozważania te przyjęto na gruncie nauk o konfliktach zbrojnych. Zaczęły one funkcjonować jako uniwersalne odniesienie cechujące charakterystyczne elementy konfliktów asymetrycznych.

13 Zob. Stownik wyrazów obcych, Warszawa 1980, s. 290. Por. Webster's New World Dictionary, wyd. 2, New York 1986, s. 687.

14 M.A. Piotrowski, Konflikt nigdy nie jest prosty: amerykańska teoria i doktryna wojen oraz przeciwników hybrydowych, „Sprawy Międzynarodowe” 2015, nr 2, s. 13.

15 A. Gruszczak, Hybrydowość wspótczesnych wojen - analiza krytyczna, [w:] Asymetria i hybrydowość. Stare armie wobec nowych konfliktów, red. B. Zapała, W. Sokoła, Warszawa 2011, s. 9-17.

16 J. Nemeth, Future war and Chechnya: A case for hybrid warfare, Monterey, CA 2002, http://calhoun. nps.edu/bitstream/handle/10945/5865/02Jun_Nemeth.pdf?sequence=1 (dostęp: 14 marca 2017). 


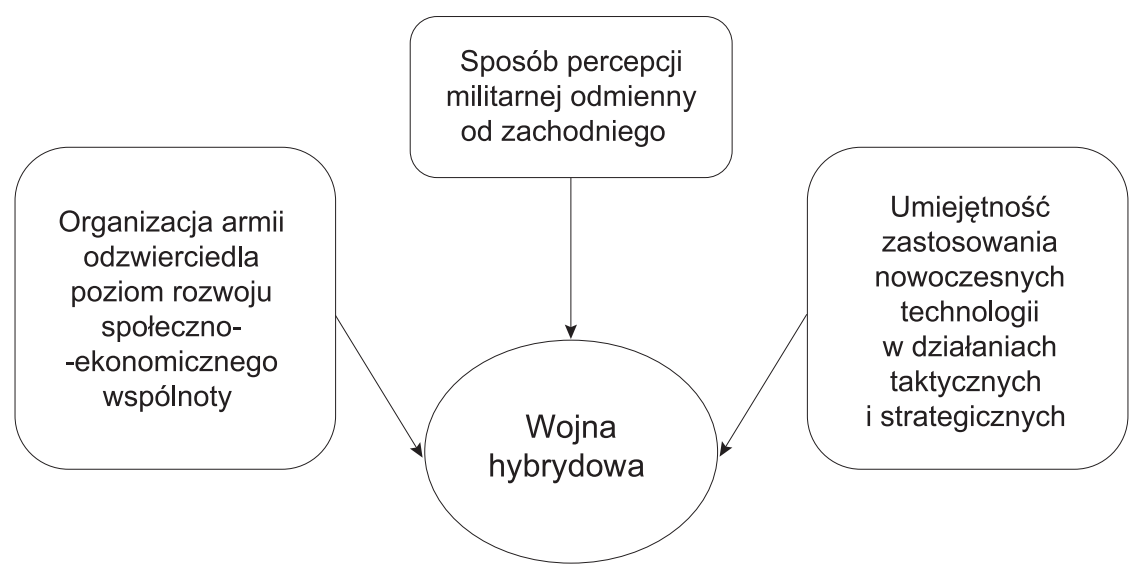

Rycina 2. Charakterystyczne cechy wojny hybrydowej

Źródło: W.J. Nemeth, Future war and Chechnya: A case for hybrid warfare, Monterey, CA 2002, http://calhoun.nps. edu/bitstream/handle/10945/5865/02Jun_Nemeth.pdf?sequence=1.

Dokonując zestawienia analizowanych terminów, tj. asymetrii i hybrydowości, można pokusić się o stwierdzenie, iż pojęcia te są z sobą bardzo ściśle skorelowane, niemniej jednak nie mogą być stosowane zamiennie, a więc funkcjonować jako swoiste synonimy. Analizowane terminy opisują podobne sfery oddziaływania oraz właściwości, jednakże każdorazowo należy dokonywać rozgraniczenia ich interpretacji.

\section{NATO w obliczu nowych zagrożeń}

Obecne środowisko, w jakim funkcjonuje NATO, uległo radykalnym przemianom od czasu założenia organizacji w 1949 r. Podlega ono ciągłym zmianom, które wymuszają jednocześnie podejmowanie procesów adaptacyjnych. Upadek Związku Radzieckiego, a w konsekwencji zakończenie zimnowojennej konfrontacji, spowodował, uwolnienie wielu dotychczas nieznanych procesów oraz zjawisk. Ewolucja charakteru zagrożeń skutkowała koniecznością zmiany dotychczasowej percepcji środowiska bezpieczeństwa. Za główny czynnik destabilizacyjny funkcjonowania Sojuszu uznano groźbę konfliktu zbrojnego $\mathrm{w}$ jego najbliższym otoczeniu. Konieczne było jednak rozszerzenie katalogu zagrożeń o zagrożenia asymetryczne, tworzone głównie poprzez aktywność podmiotów pozapaństwowych. Warto także nadmienić, iż działania podmiotów asymetrycznych związane są z groźbą zarówno posiadania, jak i samego wykorzystania broni masowego rażenia. Dodatkowym zagrożeniem związanym z procesem globalizacji jest także możliwość wykorzystywania nowoczesnej technologii, między innymi szeroko ujmowanej sfery cyberprzestrzeni, do wykonywania ataków. Działalność tego typu stanowi coraz powszechniejszą tendencję wśród podmiotów pozapaństwowych. 
Przechodząc dalej, należy podkreślić, iż do 2014 r. członkowie Paktu Północnoatlantyckiego $\mathrm{w}$ głównej mierze skupiali się na przygotowaniu reakcji na zagrożenie utożsamiane z eskalacją konfliktu o charakterze konwencjonalnym. Szacowano ryzyko wystąpienia konwencjonalnego konfliktu na terytorium państw-członków. Dopiero po 25 latach od zakończenia zimnej wojny NATO musiało uznać, iż zagrożenie wybuchu konfliktu nieregularnego we wschodniej Europie stało się ponownie realne ${ }^{17}$.

Potwierdzeniem tej tezy była eskalacja konfliktu rosyjsko-ukraińskiego w 2014 r., charakteryzującego się oddziaływaniem w sferze nieregularnej. W wypadku Federacji Rosyjskiej miało to być oddziaływanie na rosyjskojęzyczną mniejszość narodową zamieszkującą tereny wschodniej Ukrainy, a więc oddziaływanie w sferze etycznej i kulturowej.

Agresja rosyjska bazowała również na wykorzystywaniu niestabilnej sytuacji politycznej Ukrainy oraz na sferze informacyjnej, przez którą rozumieć można stosowanie lokalnej i międzynarodowej propagandy mającej ukryć rzeczywisty obraz panującej sytuacji. Wszystkie z tych działań poparte były działalnością militarną, do której wykorzystywano regularne oddziały zbrojne, jak i „zielone ludziki”, czyli żołnierzy w mundurach armii rosyjskiej, którzy pozbawieni zostali wyraźnych dystynkcji i emblematów świadczących o ich przynależności narodowej.

Należy podkreślić, iż wojna hybrydowa, jaką niewątpliwie stanowił konflikt na Ukrainie w 2014 r., przejawiała się w trzech wymiarach. Pierwszy dotyczył bezpośredniego wymiaru militarnego, tj. prowadzenia konwencjonalnych działań zbrojnych. Kolejny element stanowiła działalność w sferze psychologicznej. Ostatni natomiast polegał na stosowaniu szerokiej gamy zabiegów mających na celu szerzenie międzynarodowej propagandy ${ }^{18}$.

Co prawda Sojusz zdawał sobie sprawę z zagrożenia, jakie niósł za sobą narastający konflikt na linii Federacja Rosyjska-Ukraina, niemniej jednak nie potrafił wypracować skutecznych mechanizmów zaradczych przyczyniających się do rozwiązania sporu. Najtrudniejszą kwestią okazało się przełamanie dotychczasowej niejednomyślności organów przedstawicielskich oraz reprezentantów poszczególnych państw.

Kolejnym zagrożeniem asymetrycznym, w obliczu którego stanęło NATO, jest kwestia terroryzmu, w tym terroryzmu morskiego. W ujęciu Paktu Północnoatlantyckiego terroryzm morski ściśle odnosi się do kwestii terroryzmu międzynarodowego i ujmowany jest jako „bezprawne użycie siły lub przemocy przeciwko osobom albo też mieniu podejmowane z zamiarem przymuszenia lub zastraszenia rządów i/lub społeczeństw dla osiągnięcia politycznego, religijnego lub ideologicznego celu" 19 .

Ataki z 11 września $2001 \mathrm{r}$. spowodowały, iż postrzeganie przez NATO zagrożeń terrorystycznych uległo znacznej zmianie. W obliczu tragicznych wydarzeń i narastającej groźby kolejnych ataków na członków Paktu Sojusz podjął decyzję o utworzeniu tzw. Sił Odpowiedzi NATO (Nato Response Force), czyli zaawansowanych technologicznie

\footnotetext{
17 M. Gocuł, Sojusz gwarantem stabilizacji, „Przegląd Sił Zbrojnych” 2015, nr 1, s. 41-48.

18 M. Wrzosek, Trzy wymiary wojny hybrydowej na Ukrainie, „Kwartalnik Bellona” 2015, nr 3, s. 33.

19 K. Jałoszyński, Współczesny wymiar antyterroryzmu, Warszawa 2008, s. 275.
} 
sił mobilnych zdolnych do podejmowania działań na lądzie, morzu oraz w powietrzu. Był to efekt prac szczytu paryskiego, podczas którego uzgodniono także Koncepcję Wojskową NATO w zakresie obrony przeciwterrorystycznej. Zgodnie z zapisami koncepcji uznano, iż siły Sojuszu mogą być rozmieszczone w niezbędnym miejscu i czasie, o ile Rada uzna to za konieczne ${ }^{20}$. Jak podkreśla M. Łuszczuk, kluczowym elementem przeciwdziałania zagrożeniom o charakterze terrorystycznym jest jasne określenie form obrony. Wspomniana obrona obejmuje między innymi antyterroryzm, zarządzanie kryzysowe po ataku terrorystycznym, kontrterroryzm oraz współpracę na linii wojskowej ${ }^{21}$.

Dodatkowy czynnik obrony stanowi skuteczny wywiad, a więc uzyskanie szerokiej wiedzy na temat rzeczywistych zagrożeń. Istotne w tym względzie jest stałe rozbudowywanie natowskiego systemu obrazowania i ostrzegania o sytuacji na morzu, tzw. NATO Maritime Situational Awareness ${ }^{22}$.

Warte podkreślenia jest także rozszerzenie współpracy Sojuszu z podmiotami cywilnymi w zakresie przeciwdziałania aktom terroru na morzu. Działalność ta oparta jest na współpracy NATO z flotą handlową na zasadzie wsparcia morskich operacji o charakterze militarnym, tzw. NCAGS (Nato Cooperation of Guidance for Shipping). Kooperacja zakłada działania na rzecz bezpieczeństwa na morzu poprzez likwidowanie zakłóceń pomiędzy flotą wojskową państw NATO a flotą handlową ${ }^{23}$.

Należy podkreślić, iż działania Paktu Północnoatlantyckiego w sferze zwalczania terroryzmu morskiego uległy znacznej konkretyzacji. Jak zaznacza M. Łuszczak, działania te nabrały wyraźnych ram koncepcyjnych, zakładających doskonalenie form przeciwdziałania zagrożeniom asymetrycznym na morzu ${ }^{24}$.

Jak już wspomniano, podejście Sojuszu do zagrożeń hybrydowych w ostatniej dekadzie było niejasne i mało spójne. Członkowie skupiali się przede wszystkim na szacowaniu ryzyka konsekwencji występowania tego zjawiska dla poszczególnych państw, a więc rozprawianiu nad prawdopodobieństwa eskalacji konfliktu hybrydowego na terytorium poszczególnych państw-członków. Podstawowym problemem było wypracowanie konkretnych scenariuszy opartych o zintegrowane działania mające charakter długoterminowy.

Dopiero w lipcu 2016 r. Sojusz Północnoatlantycki w sposób szczegółowy skupił się na zagrożeniach płynących ze strony podmiotów pozapaństwowych. Na Szczycie NATO, jaki miał miejsce $\mathrm{w}$ Warszawie, podjęto decyzje o charakterze polityczno-wojskowym mające stanowić rozwiązanie trudnej sytuacji, w jakiej znalazł się obecnie Sojusz. NATO wyraziło jednomyślność $w$ zakresie konieczności podejmowania ukierunkowanych działań w tworzeniu stałych struktur i mechanizmów służących zapewnieniu bezpieczeństwa regionu. W rezultacie wypracowano wiele rozwiązań doktrynalnych traktu-

${ }^{20}$ M. Łuszczak, NATO wobec asymetrycznych zagrożeń bezpieczeństwa na obszarach morskich, [w:] NATO w pozimnowojennym środowisku (nie)bezpieczeństwa, red. J. Olchowski, M. Pietraś, Lublin 2011, s. 329.

${ }^{21}$ Ibidem, s. 328.

22 Ibidem, s. 330.

23 Ibidem, s. 331.

${ }^{24}$ Ibidem. 
jących o najistotniejszych sferach bezpieczeństwa międzynarodowego, w tym kwestii Ukrainy i narastających zagrożeń o charakterze asymetrycznym.

Sojusz podkreślił swoją gotowość w kwestii przeciwdziałania zagrożeniom hybrydowym $\mathrm{w}$ ramach zbiorowej samoobrony. W efekcie spotkania przyjęto kluczowe postanowienia, które w sposób bezpośredni odnoszą się do problemu zwiększenia bezpieczeństwa flanki południowej. Postanowienia te dotyczą między innymi wdrożenia misji szkoleniowej dla irackich sił bezpieczeństwa na terytorium tego kraju oraz zacieśnienia koalicji wymierzonej przeciwko tzw. Państwu Islamskiemu.

Narastająca liczba ataków ze strony ISIS, w tym zamachy w Nicei i Berlinie, utwierdziły NATO w przekonaniu, iż dalsze bagatelizowanie tego typu zagrożeń stanowi przejaw dalekiej bezmyślności i ignorancji. Jedynym słusznym rozwiązaniem było rozprawienie się z przeciwnikiem za pomocą siły militarnej. W tym celu Sekretarz Generalny NATO podjął decyzję o wysłaniu samolotów systemu ostrzegania i kontroli AWACS (Airborne Warning and Control System) mających wesprzeć międzynarodową koalicję. Jednostki mają poruszać się w międzynarodowej przestrzeni powietrznej oraz nad Turcją.

Kolejne z przyjętych postanowień odnosi się do kwestii tzw. bezpieczeństwa transatlantyckiego. Przedstawiciele paktu założyli, iż kluczowym elementem służącym zapewnieniu trwałego bezpieczeństwa regionu będzie wzmocnienie realnej siły Sojuszu $\mathrm{w}$ regionie. Miało to zostać osiągnięte poprzez zwiększenie realnej siły militarnej w południowym i wschodnim sąsiedztwie.

Kolejny czynnik dotyczył sfery wzmocnienia wschodniej flanki, która to utożsamiana była $\mathrm{z}$ faktem rozlokowania wojsk w rejonie konfliktogennym. Miało to dotyczyć adaptacji sił sojuszniczych w formie batalionów składających się z koalicyjnych wojsk, między innymi USA, Kanady, Niemiec czy Wielkiej Brytanii. Podstawowym założeniem tej decyzji było stałe zwiększanie współpracy przy wzmacnianiu struktur obronnych Ukrainy.

Sojusz zwrócił także uwagę na konieczność wzmocnienia obrony przeciwrakietowej mającej za zadanie ochronę ludności przed nieprzyjacielskim atakiem pocisków balistycznych wymierzonych przeciwko członkom sojuszu. Dodatkowo podjęto działania zmierzające do zintensyfikowania współpracy natowskiej w cyberprzestrzeni.

Na szczycie warszawskim podjęto także decyzję o przedłużeniu misji Resolute Support w Afganistanie, której celem jest przygotowanie dowództw afgańskich sił bezpieczeństwa oraz instytucji podległych Ministerstwu Obrony Narodowej i Spraw Wewnętrznych do samodzielnego zarządzania i kierowania w sposób gwarantujący utrzymanie bezpieczeństwa. W ramach misji przewidziano:

- utrzymanie misji Resolute Support po 2016 r.,

— zapewnienie finansowania afgańskich sił bezpieczeństwa do 2020 r.,

- utrzymywanie Stałego Partnerstwa (tzw. Enduring Partnership) Sojuszu z Afganistanem $^{25}$.

Dodatkowym elementem, na jakim skupiono się podczas szczytu, była kwestia pomocy dla pogrążonej w wojnie Ukrainy. Szefowie państw zadecydowali o udzieleniu

25 P. Soloch, P. Pietrzak, Szczyt NATO w Warszawie: uwarunkowania, rezultaty, wnioski dla Polski, „Bezpieczeństwo Narodowe" 2016, nr 37-40, s. 13. 
pomocy w ramach pięciu obszarów tematycznych, tj. doradztwa w zakresie ochrony elementów infrastruktury krytycznej, reformy sektora bezpieczeństwa i obrony, edukacji i szkoleń, zwalczania improwizowanych materiałów wybuchowych oraz utylizacji przestarzałej broni. Dodatkowo współpraca opierać się będzie na wzmocnieniu zdolności bojowych ukraińskich zbrojnych oraz reformie sektora bezpieczeństwa i obrony ${ }^{26}$.

Kluczowa kwestia dotyczyła również podjęcia decyzji o rozpoczęciu operacji Sea Guardian, której głównym zamierzeniem ma być walka z narastającym kryzysem migracyjnym na Morzu Śródziemnym. Podstawą prowadzenia wspomnianej operacji była misja Active Endeavour rozpoczęta w 2001 r. w Cieśninie Gibraltarskiej. Celem pierwotnej operacji była ochrona szlaków żeglugowych i jednostek cywilnych przed atakami terrorystycznymi ${ }^{27}$.

Podsumowując kwestię Szczytu NATO w Warszawie, należy podkreślić, iż po raz pierwszy od 2014 r. Pakt wyraził jednomyślność w kwestii przeciwdziałania zagrożeniom niekonwencjonalnym. Co prawda szczyt NATO w Newport wskazywał na występowanie tego typu zjawisk, niemniej jednak były to rozważania o charakterze jedynie teoretycznym, których celem było wyszczególnienie katalogu nowych wyzwań i zagrożeń. Dopiero w efekcie warszawskiego Szczytu Pakt Północnoatlantycki zdołał opracować szczegółowy katalog działań, jakie należy podjąć w celu reagowania, a przede wszystkim obrony przed kolejnymi atakami.

P. Pacula podkreśla, iż Szczyt NATO w Warszawie odbywał się w kluczowym momencie dla bezpieczeństwa europejskiego. Jak wskazuje, region europejski nieustannie boryka się z narastającą liczbą wyzwań o charakterze konwencjonalnym przy jednoczesnym pojawianiu się nowych - wykraczających poza utarte schematy myślowe. Jesteśmy świadkami kryzysu instytucji europejskich oraz wzrostu izolacjonistycznych trendów. W obliczu wspomnianych zjawisk tak istotny jest powrót Sojuszu do roli gwaranta bezpieczeństwa Europy. Dlatego tak ważne było wykazanie jedności i gotowości do stawiania czoła wyzwaniom na wszystkich kierunkach strategicznych zgodnie z polityką 360 stopni $^{28}$.

\section{Podsumowanie}

Podstawowym założeniem niniejszego artykułu było wskazanie na zmiany środowiska i otoczenia, w którym funkcjonują organizacje bezpieczeństwa globalnego, w szczególności Sojusz Północnoatlantycki. Coraz to nowe zagrożenia, w tym agresja Federacji Rosyjskiej na Ukrainę, a w konsekwencji aneksja Krymu, wymuszają podjęcie przez NATO zdecydowanych kroków zmierzających ku załagodzeniu sytuacji oraz niedopuszczeniu

26 http://www.defence24.pl/405893,10-najwazniejszych-decyzji-podjetych-na-szczycie-nato-w-warszawie (dostęp: 14 grudnia 2016).

27 http://www.nowastrategia.org.pl/szczyt-nato-operacja-sea-guardian-na-morzu-srodziemnym-iawacs-przeciw-isis/ (dostęp: 14 grudnia 2016).

28 P. Pacuła, Państwa Quadu NATO wobec szczytu w Warszawie, „Bezpieczeństwo Narodowe” 2016, nr 37-40, s. 35-50. 
do eskalacji podobnych zjawisk w przyszłości. Zamierzeniem autorki przedstawionego opracowania było więc ukazanie zagrożeń dla Sojuszu ze strony podmiotów niekonwencjonalnych, a więc przeciwników asymetrycznych, które odnosiły się do kwestii agresji rosyjskiej w regionie wschodniej Ukrainy.

Rezultatem starań o wskazanie różnicy pomiędzy pojęciem asymetryczności a hybrydowości współczesnych zagrożeń jest wskazanie, w jaki sposób NATO próbuje zaradzić pojawiającym się współcześnie nieregularnym zagrożeniom. W tym celu przytoczone zostały najistotniejsze rozwiązania w zakresie między innymi terroryzmu morskiego oraz zagrożeń asymetrycznych odnoszących się do kwestii konfliktu ukraińskiego: działania Nato Response Force oraz działania strategiczne określone podczas Szczytu NATO w Warszawie.

\section{Bibliografia}

Bąk T., Udział i sojusznicze współdziałanie żotnierzy WP w operacji pokojowej NATO w Kosowie, AON, Warszawa 2002.

Dobrowolska-Polak J., Międzynarodowa solidarność. Operacje pokojowe ONZ, NATO i UE, „IZ Policy Papers" 2009, Nr 3.

Gocuł M., Sojusz gwarantem stabilizacji, „Przegląd Sił Zbrojnych” 2015, nr 1.

Gruszczak A., Hybrydowość wspótczesnych wojen - analiza krytyczna, [w]: Asymetria i hybrydowość. Stare armie wobec nowych konfliktów, red. B. Zapała, W. Sokoła, Biuro Bezpieczeństwa Narodowego, Warszawa 2011.

http://www.defence24.pl/405893,10-najwazniejszych-decyzji-podjetych-na-szczycie-nato-w-warszawie.

http://www.do.wp.mil.pl/info/zadania5.

http://www.nato.int/nato-welcome/index.html.

http://www.nowastrategia.org.pl/szczyt-nato-operacja-sea-guardian-na-morzu-srodziemnym-i-awacsprzeciw-isis/.

http://www.stosunki.pl/sites/default/files/images/Traktat\%20P\%C3\%B3\%C5\%82nocnoatlantycki.pdf.

http://www.unic.un.org.pl/misje_pokojowe/globalne_bezpieczenstwo.php\#zk.

Jałoszyński K., Wspótczesny wymiar antyterroryzmu, Warszawa 2008.

Joint Publication 3-07, „Joint Doctrine for Military Operation Other Than War”, June 1995, s. I-1.

Łuszczak M., NATO wobec asymetrycznych zagrożeń bezpieczeństwa na obszarach morskich, [w:] NATO w pozimnowojennym środowisku (nie)bezpieczeństwa, red. J. Olchowski, M. Pietraś, Wydawnictwo Uniwersytetu Marii Curie-Skłodowskiej, Lublin 2011.

Marszałek M., Operacje wsparcia pokoju według poglądów NATO, AON, Warszawa 1999.

Nemeth J., Future war and Chechnya: A case for hybrid warfare, Monterey, CA 2002, http://calhoun.nps.edu/ bitstream/handle/10945/5865/02Jun_Nemeth.pdf?sequence=1.

Pacuła P., Państwa Quadu NATO wobec szczytu w Warszawie, „Bezpieczeństwo Narodowe” 2016, nr 37-40.

Piotrowski M.A., Konflikt nigdy nie jest prosty: amerykańska teoria i doktryna wojen oraz przeciwników hybrydowych, „Sprawy Międzynarodowe” 2015, nr 2.

Rokiciński K., Zagrożenia asymetryczne w Regionie Bałtyckim, Warszawa 2006.

Słownik wyrazów obcych, PWN, Warszawa 1980.

Soloch P., Pietrzak P., Szczyt NATO w Warszawie: uwarunkowania, rezultaty, wnioski dla Polski, „Bezpieczeństwo Narodowe" 2016, nr 37-40.

Szubrycht T., Analiza podobieństw operacji militarnych innych niż wojna oraz działań pozwalających zminimalizować zagrożenia asymetryczne, „Zeszyty Naukowe Akademii Marynarki Wojennej”, nr 1, 2006.

Webster's New World Dictionary, wyd. 2, Prentice Hall Press, New York 1986. 


\section{New challenges for the North Atlantic Alliance. NATO in the face of hybrid threats}

Keywords: hybrid threats, hybrid war, asymmetry, NATO, MOOTW (military operation other than war)

Summary

The end of the cold war and, consequently collapsed of bipolar partition led to the situation of appearing new, unknown threats in the security and defense sphere. The representatives of North Atlantic Alliance face the challenge, which result was taking decisive steps to counteract and level newly created threats. The following article provides outline of the problem to apply a reality which NATO is. The author try to ask the question: "Do the main safety pillar have the mechanism to counteract and prevent unwanted scenarios in multimodal character as hybrid threats?". 